\title{
Joseph Skoda 1805-81: a centenary tribute to a pioneer of thoracic medicine
}

\author{
ALEX SAKULA \\ From Redhill General Hospital, Redhill, Surrey
}

ABSTRACT Joseph Skoda was born on 5 December 1805 in Pilsen, Bohemia, and studied medicine in Vienna, where he became professor of medicine in 1846 . His clinical researches into cardiopulmonary disease at the Allegemeine Krankenhaus were complementary to the pathological anatomical studies carried out there by Karl von Rokitansky. Skoda had been stimulated by the pioneer work on percussion and auscultation of the Paris school of medicine, but his own researches simplified the classification of physical signs taught by the French masters, Laënnec and Piorry. Skoda's findings were collected in his magnum opus, Abhandlung über Perkussion und Auskultation (1839), in which he described his famous eponymous physical sign, "Skodaic resonance." Skoda was sceptical of the medical treatment then available and was labelled a "therapeutic nihilist." Together with Rokitansky, he helped to make Vienna, for a time, the focal point of medical teaching in Europe. He died on 13 June 1881 .

Vienna in the mid-nineteenth century provided the backcloth for the partnership of two remarkable men of medicine, both born in Bohemia, one the illustrious German pathologist Karl von Rokitansky, and the other the great Czech clinician Joseph Skoda. Their collaboration placed the Vienna school of medicine, for a time, in the forefront of the advance of medical knowledge. The centenary of the death of Joseph Skoda affords an opportunity to recall the story of his life and his contribution to the practice of clinical medicine, especially the study of thoracic disease.

\section{Birth and early years}

Joseph Skoda was born on 5 December 1805 in Pilsen, then in Bohemia, now a part of Czechoslovakia (fig 1). His father, a poor locksmith, had three sons. Joseph's elder brother, Franz Skoda (1802-88) became a physician and distinguished himself in public health in Bohemia. His younger brother, Johann Skoda, followed his father's craft, and later founded a locomotive factory, which developed into the great Skoda works, famous for the manufacture of armaments and, in modern times, the Skoda automobile industry.

Address for reprint requests: Dr A Sakula, Redhill General Hospital, Earlswood Common, Redhill, Surrey RH1 6LA.
As a child, Skoda suffered from a tuberculous illness. His parents were keen that he should enter the priesthood, but he was determined to study medicine, no doubt influenced by his elder brother's choice of career. The problem was how to finance his studies, but fortunately this was taken care of by a Madame Bischoff, wife of a Viennese manufacturer, who befriended Skoda, and in 1825 he walked from Pilsen to Vienna (a six-day journey on foot) and began his medical studies. In his preclinical period, he was taught mathematics and physics by Professor Julius Baumgärtner and took a special interest in acoustics, which was later to serve him in good stead. He qualified MD in 1831, aged 25 years, with a dissertation entitled De Morborum Divisione, and proceeded to Pilsen to take over his brother Franz's post of cholera doctor, as the pandemic was then approaching Bohemia. After one year, this type of medical practice no longer appealed to Skoda and he decided to return to Vienna to continue his medical studies. In 1833, he took up the unsalaried post of Sekundarzt (Assistant Physician) at the Allgemeine Krankenhaus (General Infirmary) where he soon made the acquaintance of Rokitansky. ${ }^{1}$

\section{The Vienna medical school}

The old Vienna school of medicine dated from the mid-eighteenth century, the first professor of medicine 


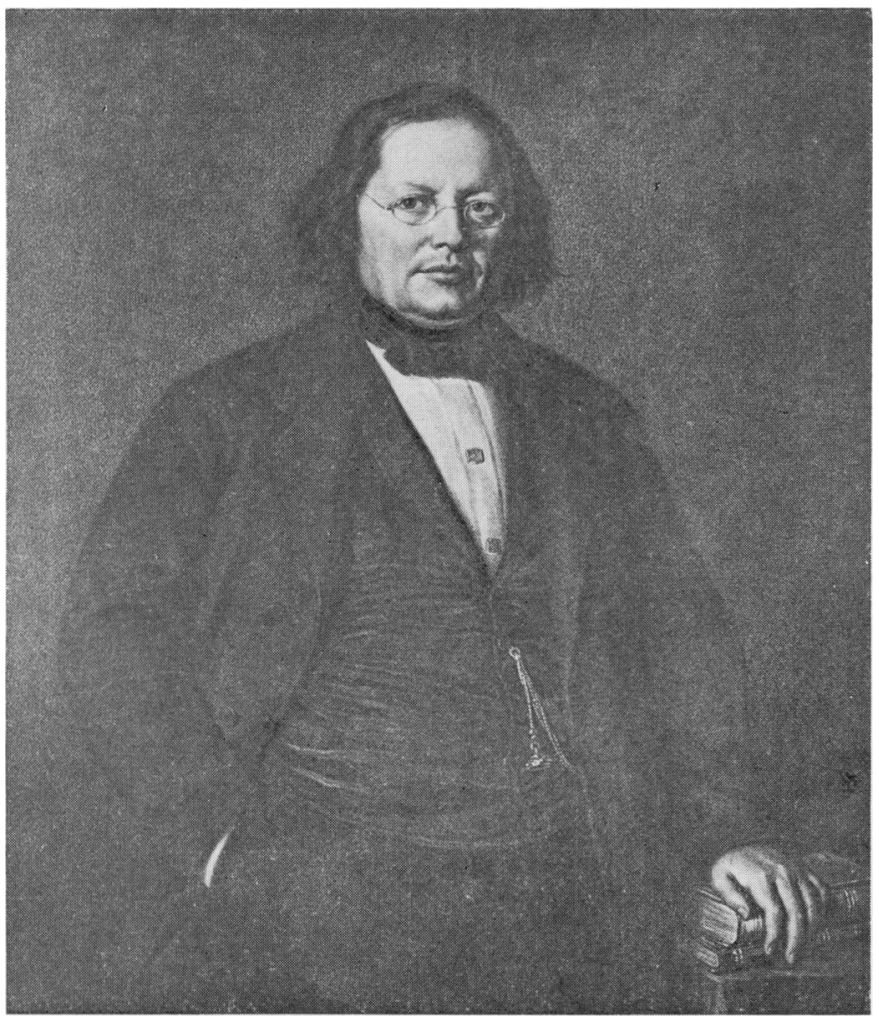

Fig 1 Joseph Skoda. Lithograph by J Bauer after portrait by $G$ Gaul

being Gerhard van Swieten (1700-72), who had been a pupil of Hermann Boerhaave (1668-1738) in Leyden. Van Swieten was succeeded by Anton de Haen (1704-76), who was followed by Maximilian Stoll (1742-88) and then by Johann Peter Frank (17451821). The Allgemeine Krankenhaus opened in 1784, and the Josefinum (University Medical School) in 1785. The fame of the Vienna school of medicine spread through Europe, especially in the fields of ophthalmology and obstetrics, but to a lesser degree in internal medicine. ${ }^{2}$

The early nineteenth century however saw a great decline in the influence of the old Vienna school, but by the 1830s it experienced a resurgence and the new Vienna school came into being, centred around the remarkable pathological studies of Rokitansky coupled with the clinical researches of Skoda. ${ }^{3}$

The Vienna school of medicine differed from the Parisian in that necropsies and morbid anatomy were not in the hands of the clinicians. Karl von Rokitansky (1804-78) was prosektor (morbid anatomist) at the Allgemeine Krankenhaus and in 1844 became Professor of Pathological Anatomy.

Although the foundations of pathological anatomy had been laid by Giovanni Battista Morgagni
(1682-1771) in his great work, De Sedibus et Causis Morborum (1761), and this knowledge was later extended by the French clinician-pathologists (especially Laënnec) and the British masters (in particular, Matthew Baillie (1761-1823)), it was Rokitansky whom Rudolf Virchow (1821-1902) considered to be the first true pathological anatomist. Rokitansky performed necropsies on all patients dying in the Allgemeine Krankenhaus, and these were said to have numbered 30000 . Working initially in a primitive wooden shed and later in the Pathological Institute, and assisted by Jakob Kolletschka (180347), his necropsy demonstrations became a focal teaching point where clinical and pathological findings were correlated. This new knowledge was described by Rokitansky in his great Handbuch der Pathologischen Anatomie, published in three volumes (1842-6).

\section{Skoda's clinical researches}

The physician of the old Vienna school of medicine whose name is now most remembered is Leopold Auenbrugger (1722-1809), who introduced percussion as a diagnostic technique and was the author 
of Inventum Novum which, when published in 1761, made little impact on contemporary medical practice 4 . Auenbrugger never became a professor, and Van Swieten, de Haen, and Frank did not recognise the importance of Auenbrugger's work, although Stoll referred to it in his Aphorisms, which later influenced Jean Nicholas Corvisart (1755-1821) who translated Inventum Novum from the original Latin into French. Its publication in Paris in 1808 made an enormous impact on the early nineteenth century French physicians, first Gaspard Laurent Bayle (1774-1816) and then René Théophile Hyacinthe Laënnec (1781-1826). Laënnec's invention of the stethoscope (1816) and the publication of his masterpiece $D e$ L'Auscultation Médiate (1819) revolutionised clinical medicine, and Paris, rather than Vienna, became the major European medical centre. ${ }^{5}$ Laënnec's diagnostic techniques were further improved by Pierre Adolphe Piorry (1794-1879) who, by his invention of the pleximeter, made percussion a more refined technique. ${ }^{6}$

Skoda was undoubtedly influenced by these developments in Paris, and gave full credit to Laënnec and Piorry, but he was not satisfied with their description of the techniques and nomenclature of percussion and auscultation. There was no one in Vienna to give him practical instruction and he decided to make a study of the new clinical methods himself. Skoda believed in observation and not speculation, and he did not consider himself bound by the traditional and empirical French usages. His aim was to convert diagnosis from an art into a science.

\section{Skoda's work on percussion and auscultation}

Laënnec had described percussion sounds in terms such as "bruit de pot felé" (cracked pot sound). Piorry's classification was equally empirical and based on the organ being percussed-for example, the heart, lung, stomach, liver, thigh. Skoda asked: what is a physical sign? One hears a "lung sound" over the lung, and a "hepatic sound" over the liver, so what does one hear on percussing hepatised lung? The French school maintained that one could only learn these sounds from an experienced master, but Skoda had no intention of visiting Paris to acquire this esoteric knowledge. He therefore tackled the problem from the point of view of physics and acoustics, and experimented on both the living patient and the cadaver. His repeated examinations of his patients led to complaints, so that he was for a time forced to take over a mental ward, but he found these patients equally suitable for his investigations! Skoda finally described four variables of percussion sound: (1) full-empty, (2) clear-dull, (3) tympanic- nontympanic, (4) high-low. The term tympanic had first been used by Piorry, but Skoda defined it more precisely and gave it a scientific basis.

Skoda applied himself similarly to the study of the sounds heard through the stethoscope. The earlier French writers had described the sounds heard in the thorax by comparison with the sounds of naturefor example, owls, dogs, sawing wood, creaking new leather (Laënnec's "bruit de cuir neuf"). Skoda however named the sounds on a physical basis, by musical pitch and tone.

In the lung, he classified breath sounds as (1) pulmonary or vesicular, (2) bronchial, (3) amphoric echo and metallic tinkling, (4) indeterminate. Rales he classified as (1) vesicular, (2) consonating, (3) dry crepitant, (4) amphoric and metallic tinkling, (5) indeterminate. He also described pleural friction. Voice conduction he explained on the basis of the theory of consonance, and he objected to Laënnec's distinction between bronchophony and pectoriloquy which he considered to have identical significance, nor did he accept the term aegophony.

In the heart, Skoda first distinguished the heart sounds from murmurs, relating the latter to abnormalities in individual valves - for example, aortic and mitral incompetence. Together with his pathologist colleague Kolletschka he made a special study of pericarditis and the pericardial friction rub, a sound which had not been described by Laënnec. In this manner, Skoda amplified yet simplified the complex nomenclature of the French school and laid the foundations of the clinical physiology of heart disease.

Skoda's discoveries in the field of clinical diagnosis were published in Vienna in 1839 in his major work Abhandlung über Perkussion und Auskultation. ${ }^{7}$ This medical classic, a volume of 305 pages, was dedicated to his patron, Ludwig von Turkheim (1777-1846), physician to Duke Franz Karl of Austria (fig 2). It passed through six editions, and in 1853 was translated into English by William Orlando Markham (1818-91), physician and cardiologist to St Mary's Hospital and editor of the British Medical Journal. ${ }^{8}$

The eponymous physical sign, "Skodaic resonance", the tympanic sound heard on percussion above a pleural effusion, was described in the monograph as follows:

"That the lungs, partially deprived of air, should yield a tympanic, and, when the quantity of air in them is increased, a non-tympanic sound, appears opposed to the laws of physics. The fact however is certain, and is corroborated both by experiments on the dead body (which will be presently referred to), and also, by this constant phenomenon, viz: that when the lower portion of the lung is entirely compressed by any pleuritic effusion, and its upper 


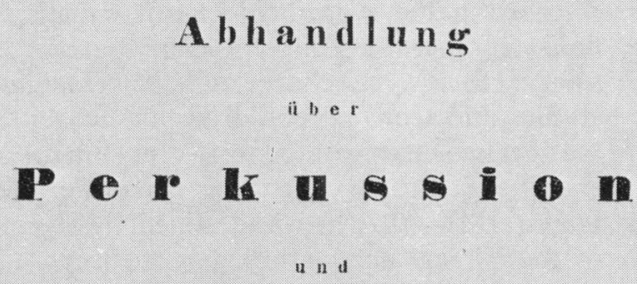

Aus un Itation.

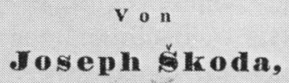

Dr. der Medicin, Mitglied der medicinischen Fakultät und der k, k. Gesellschaft der Ärzte in Wien.

Wien, 1839 .

Bei J. G. Ritter von Mösle's Witwe \& Braumüller. Graben Nr. 1144.
Fig 2 Title page of Abhandlung über Perkussion und Auskultation (1839) portion reduced in volume, the percussion sound at the upper part of the thorax is distinctly tympanitic".

Interestingly, at the end of the monograph, Skoda described uses for the stethoscope other than for examination of the thorax, including the following: the friction of a catheter on a stone in the bladder can be heard more distinctly by placing the stethoscope on the pubis!

\section{Skoda's therapeutic scepticism and nihilism}

Coupled with Skoda's doubts about other physicians' techniques in clinical diagnosis, he was equally sceptical, if not contemptuous, of the efficacy of the therapeutic methods then in fashion, which consisted chiefly of bleeding, application of leeches, sweating, and polypharmacy with bizarre and useless galenicals. As far as Skoda was concerned,
"Ach das ist jar alles eins" (They are all equally useless). This scepticism of the old remedies did not prevent him experimenting and attempting, by simple statistical means, to evaluate newer treatments. Thus, he gave a trial to salicylates, to chloral, and to inhalations of turpentine, and he accepted the efficacy of mechanical relief, for example, aspiration of pleural fluid. In 1840, together with his surgical colleague, Franz Schuh (1804-60), the first pericardial aspiration was carried out.

Skoda's pupils however extended his views a stage further, from therapeutic scepticism to therapeutic nihilism. They preached: "Nichstun sei das Beste in der innerin Medizin" (To do nothing is the best in internal medicine). ${ }^{9}$ Although the Vienna medical school was now famous as a diagnostic centre, its reputation was limited because of this attitude to therapy, and Skoda was certainly not a popular figure among the Viennese pharmacists! 


\section{Skoda's later career}

In 1835, Skoda had started private courses of lectures and soon became renowned as a clinical teacher. Czech doctors came to listen to him in Vienna and returned with the new knowledge to Prague. In 1839, his post as assistant physician at the Allgemeine Krankenhaus ended, and for nine months he worked as armenartz (doctor for the poor) in St Ulrich outside Vienna. An event then occurred which was to improve his fortunes. The Duke of Blacas (the French Minister to Austria) was seriously ill with an unexplained abdominal complaint, and all the eminent physicians of the time were perplexed. Turkheim called in Skoda who diagnosed a leaking abdominal aortic aneurysm, prognosed imminent death, and necropsy confirmed his diagnosis. Turkheim said: "Wenn ich jünger wäre, würde ich bei ihnen lernen" (If I were younger, I would be taught by you).
It was after this success that Skoda was in 1840 placed in charge of the newly opened wards for chest diseases in the Allgemeine Krankenhaus, and the next year became full physician, but still with no salary. He now had charge of $\mathbf{4 2}$ beds and his clinical studies and teaching could be pursued unhindered. $\mathrm{He}$ also had charge of the wards for skin diseases, but soon handed these over to his friend Ferdinand von $\overrightarrow{\vec{H}}$ Hebra (1816-80), who was destined, by his correlation of the clinical and pathological features, to do for skin diseases what Skoda had done for cardiothoracic disease.

After an attack of typhus in 1841, Skoda took a combined convalescent and study holiday, and he and Rokitansky travelled to Strasbourg, Paris, London, 을 and Dublin. On his return, foreign students flocked to his clinics, where his diagnostic skills were much $\subsetneq$ admired. His own clinical sense developed and he excelled in "blitz-diagnostik" (snap-diagnosis), but

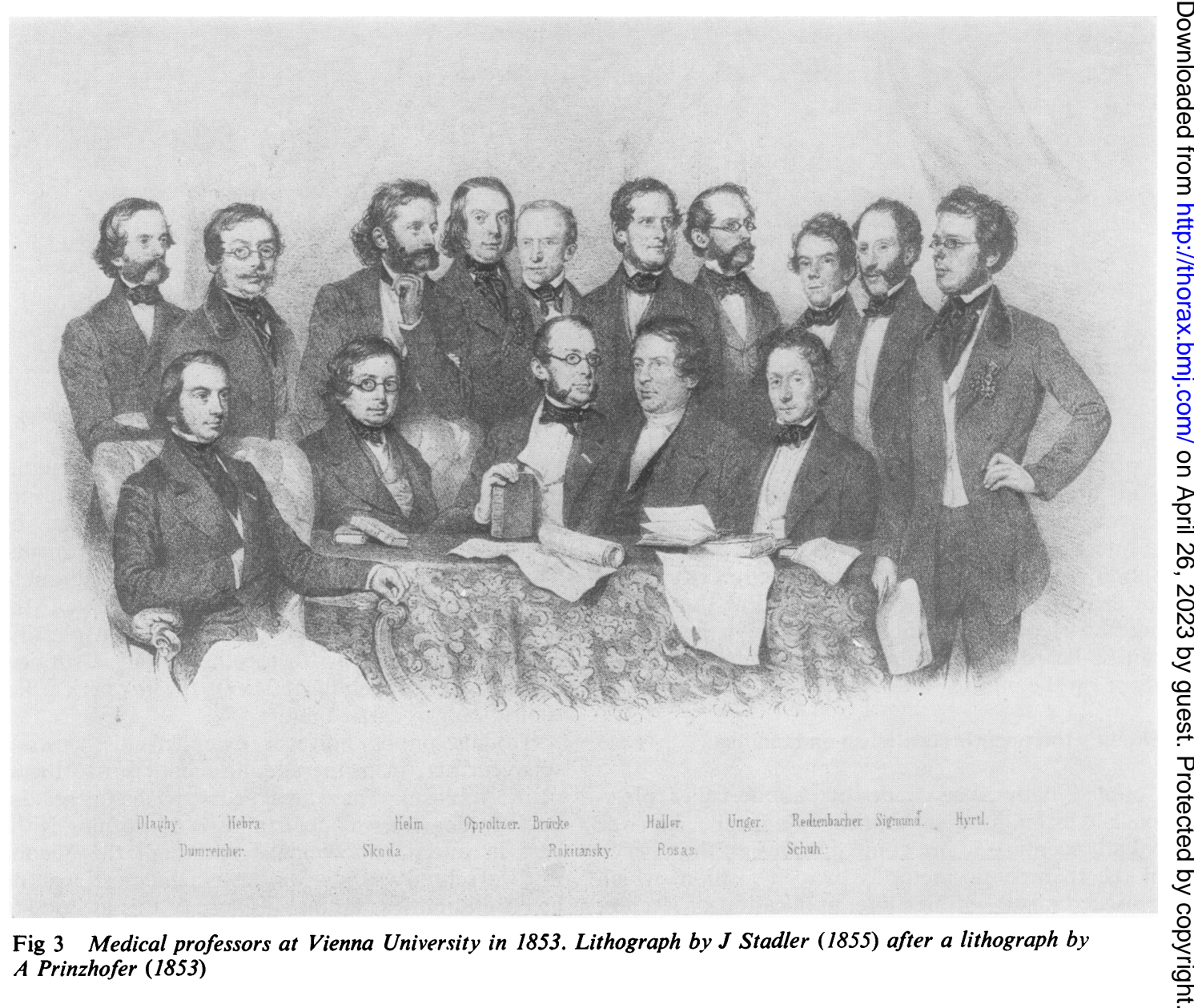


he taught his students that they must believe only what they saw with their own eyes or heard with their own ears. Careful systematic examination and consideration of the underlying organ pathology must precede diagnosis by exclusion. ${ }^{10}$

There had at first been opposition to Skoda's advancement in Vienna, possibly because he was Czech, but eventually in 1846 he was given the chair of internal medicine in the Vienna medical school. As was the custom, he gave his inaugural address in Latin. Until that time, all lectures in Vienna were in Latin, but Skoda instituted lectures in the German tongue. There were now more students than Skoda could cope with, and a second chair under another Bohemian physician, Johann Ritter von Oppolzer (1808-71) was created. In 1849 Skoda produced an important report on the reform of medical education. Rokitansky was now Dean of the medical faculty, and Skoda Vice-Dean.

As professor of medicine, he continued to concentrate his attention on thoracic disease, with emphasis on the heart rather than on the lungs, although he was also involved with general medical problems. That Skoda's views were ahead of his time is indicated by his conviction that cholera and enteric diseases were water-borne diseases, and he had the source of Vienna's water supply changed to higher mountain springs, leading to a dramatic reduction in the incidence of these diseases in the city.

It was at this time that Ignaz Phillip Semmelweiss (1818-65), "the immortal Magyar", was first assistant to Professor Johann Klein, and was carrying out his great work in reducing the incidence of puerperal fever in the midwifery wards of the Allgemeine Krankenhaus, proving that the condition was caused by contamination of the uterus by the medical attendants, whose hands conveyed an infectious agent from other patients with septic wounds or from handling septic necropsy material. Semmelweiss' views met with great opposition, led by his chief, Professor Klein, but Skoda (together with von Hebra) championed Semmelweiss at a meeting of the Academy of Science in 1849 , although without success. This controversy was to end tragically when Semmelweiss became melancholic and ironically met his death by developing septicaemia after an accidental necropsy wound.

By 1850 the work of Rokitansky and Skoda had made Vienna famous as a centre for the study of internal diseases, but other specialities also developed and flourished: dermatology (von Hebra), surgery (Schuh and Billroth), ophthalmology (Artl and Jaeger), otology (Politzer), and laryngoscopy (Schnitzler) (fig 3). Another star of the school was Josef Hyrtl (1810-94), whose great anatomical textbook, Lehrbach der Anatomie des Menschen (1846) passed through 22 editions.
It was now said that no European or American doctor's education was complete until he had spent some time in Vienna. Sir William Robert Wilde (1815-76), the father of Oscar Wilde, and famous Irish otologist, visited Vienna in 1843 and described Rokitansky's and Skoda's clinics. He wrote: "This school comes nearer to the principles aimed at by the immortal Laënnec than any other since its day".11

The fame of Vienna lasted through to the 1850s, when the focus of medical activity in Europe now shifted to Berlin. By the time that Sir William Osler (1814-1919) visited Vienna in 1874, Skoda had retired, von Hebra was now the lecturer of the Vienna school, and Rokitansky was at the end of his career (Osler attended his seventieth birthday celebration) and his clinics no longer so spectacular. ${ }^{12}$

\section{Skoda's final years and death}

For the next 20 years, Skoda's influence was paramount in the Vienna medical school. Apart from his numerous students, from home and abroad, the sick of Europe flocked to Vienna to seek his help, and in contrast with the struggles of his earlier years, he was now wealthy and was elevated to Hofrat (privy councillor). He lived simply though comfortably near the Allgemeine Krankenhaus at Reitergasse 16, an address which after his death was changed to Skodagasse 13, where there is now a commemorative plaque outside the house. He never married, and his housekeeper was a lady named Therese, who had been the bride of his pathologist colleague Kolletschka, who, like Semmelweiss, died tragically in 1847 from septicaemia after an accidental necropsy wound.

Skoda was of short stature, thin in his earlier years, although later he became top heavy. He was said to wear queer clothes, in order not to offend his tailor, who was a personal friend! When lecturing he stood stethoscope in hand, speaking German in a monotone with a Slavonic accent. With his close friends he spoke Czech. Despite the troubled times in which he lived, Skoda stayed apolitical.

Skoda retired from the chair of medicine in 1870 , aged 66 years, but as emeritus professor he continued to exert considerable influence on the medical faculty. Towards the end of his life he was troubled by gout and a cardiac disorder. He died in Vienna on 13 June 1881, and the necropsy performed by Hans Chiari (1851-1916) was of interest: it showed aortic stenosis and marked atheroma of the aorta and coronary arteries, but only old scarring of the lung apices. There was an impressive funeral attended by university dignitaries, his students, and patients, and he was buried at the Hernalser cemetery in Vienna (fig 4). 


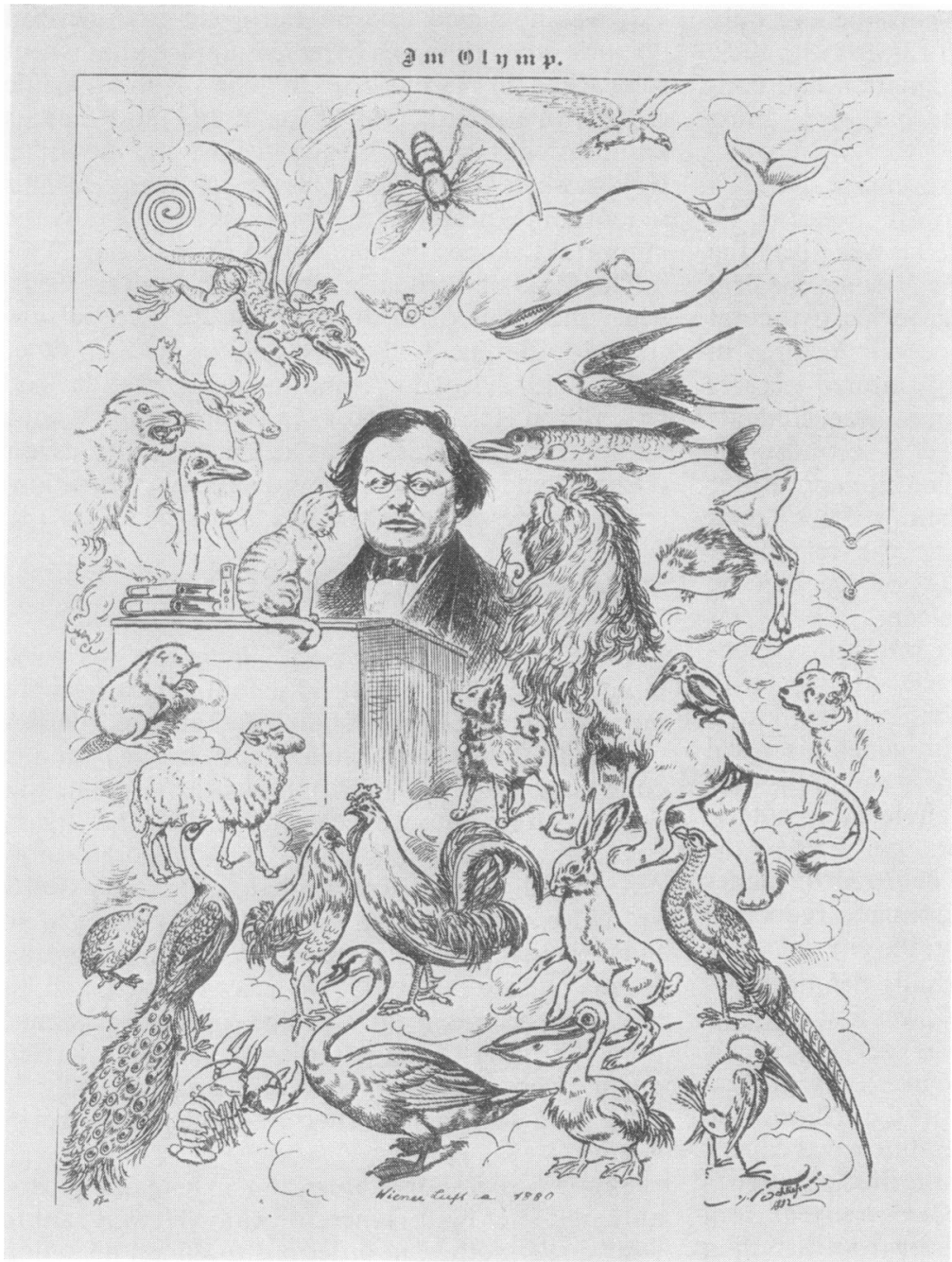

Fig 4 Joseph Skoda on Olympus Caricature by Schliessman (1882)

\section{Conclusion}

At the present time, the diagnosis of cardiac and pulmonary disease is facilitated by modern technological advances, and it is easy to forget how important the skills in eliciting physical signs were to clinicians of the nineteenth century. Joseph Skoda's contribution to the perfection of the techniques of percussion and auscultation must be appreciated in this context, and his momentous work in this field makes him one of the great pioneers of thoracic medicine.

The illustrations are reproduced by courtesy of the Wellcome Trustees.

\section{References}

1 Sternberg M. Josef Skoda. Vienna: Springer ${ }_{i=0}^{N}$

2 Neuberger M. British medicine and the Vienna school London: Heinemann, 1943.

3 Lesky E. The Vienna medical school in the 19ths century. Baltimore: Johns Hopkins University Press, 1976.

4 Sakula A. Auenbrugger: opus and opera. $J R$ Coll Phys 1977-8; 12:180-7.

5 Sakula A. In search of Laënnec: a pilgrimage toळ Quimper, Nantes and Paris. J R Coll Phys 1981 व 14:55-57.

6 Sakula A. Pierre Adolphe Piorry: pioneer of per응 cussion and pleximetry. Thorax 1979; 34:575-81. 
7 Skoda J. Abhandlung über Perkussion und Auskultation. Vienna: Mösle and Braumüller, 1839.

8 Skoda J. A treatise on auscültation and percussion. English translation by W.O. Markham. London: Highley, 1853.

9 Kussmaul A. Jugender-innerungen eines alten Arztes. Stuttgart: Bonz, 1900.
10 Wunderlich CA. Wien und Paris. Stuttgart: Hüber, 1841.

11 Wilde Sir WR. Austria, its literary, scientific and medical institutions, with notes upon the present state of science and a guide to the hospitals and sanatory establishments of Vienna. Dublin: Curry, 1843.

12 Cushing H. The life of William Osler. London: Oxford University Press, 1940. 